\title{
INFRASTRUCTURE DEVELOPMENT BY PUBLIC-PRIVATE PARTNERSHIP IN INDONESIA: A SYSTEMATIC LITERATURE REVIEW
}

\author{
Vera Mandasari ${ }^{*}$, Ersa Tri Wahyuni ${ }^{1}$ \\ ${ }^{I}$ Indonesia Department of Accounting, Faculty of Economics and Business, Padjadjaran University, \\ Dipatiukur Campus, Jl. Dipati Ukur No.35 Bandung 40132, Indonesia
}

(Received: November 2019 / Revised: December 2019 / Accepted: December 2019)

\begin{abstract}
Research on Public-Private Partnership (PPP) in Indonesia has emerged over the last decade due to the increased popularity of PPP as one of the financing schemes for the infrastructure project. This study aims to determine the trend of PPP research in Indonesia between the period of 2002 and 2019 and identify the research gap. Papers from three academic citation engines; Google scholars, Sinta and Garuda were selected based on the specific words relevant to PPP issues in Indonesia. A total of 107 papers from both international and national journals are analyzed to discover a few themes of the paper and analyze them based on the categories emerging from the themes. The analysis revealed that the quantity of the paper steadily increase from the period of 2015 and is still dominated by authors from engineering science background $(41.12 \%)$. Road (20.47\%) and Water Supply (16.54\%) are the popular objects in the study, followed by the airport (3.94\%). In terms of methodology, the case study of a PPP project has been a popular methodology chosen by 31 papers $(28.97 \%)$. The top three topics in the literature have discussed risk analysis of PPP project $(22.43 \%)$, the implementation of PPP $(22,43 \%)$ and the BOT scheme $(13,08 \%)$. The study identifies the literature gap in the accounting issues and taxation issues respectively, as well as the social impact of the PPP projects. Research on the three issues will enrich our understanding of the PPP issues in Indonesia.
\end{abstract}

Keywords: Indonesia; Infrastructure; PPP; Project

\section{INTRODUCTION}

Collaboration between government and business entity in the infrastructure development or famous as PPP (Public-Private Partnership), has been increasingly popular throughout the world as the concept of the New Public Management (NPM) widely accepted in the 1980s (Broadbent \& Laughlin, 2003; Guthrie, 1998). The concept of NPM revitalizes public services to be more modern and similar to private sector services that are considered to be better. Since the 1980s, many public services have been privatized to incorporate the value of private business culture into public services to prioritize the quality of services to the public. PPP is defined by the PPP Canada Council as a co-operation between the public and private sectors. Industry based on the expertise of each partner. Appropriate allocation of resources, risks and returns to meet clearly defined public needs.

*Corresponding author's email: mandasari_vera@yahoo.com 
This is the case since the introduction of PPP in the UK in 1997, it has been approved as an effective way of achieving value for money public infrastructure and services. PPP now records for about $15-8 \%$ of infrastructure expand in the UK and Australia. PPP, on the other hand, plays a key role in the development of infrastructure in a developing country.

For infrastructure provision, the PPP method has also developed rapidly over the past decade and has been widely discussed in international academic literature (Boardman \& Vining, 2012; Hodge \& Greve, 2009; Iossa \& Saussier, 2018). Case studies discussing infrastructure financing have been written academically in the last two decades, several of them includes the cases of health facilities and schools in the UK (Froud \& Shaoul, 2001; Khadaroo, 2008; Pollock, Shaoul, \& Vickers, 2002), highways in Spain, England and the United States (Acerete, Shaoul, Stafford, \& Stapleton, 2010; Akbiyikli, Dikmen, \& Eaton, 2011).

Government productive assets (Capital Stock) originating from PPP projects continue to increase and currently represent approximately $2 \%$ of GDP in developed countries and $7 \%$ in developing countries. A robust argument to involve the private sector in infrastructure procurement projects is generally to provide better asset quality and service quality for the same amount of resources. Since the late 1970s, PPP has started on building the infrastructures in Indonesia, e.g., the construction of the Jagorawi toll road, the first paid freeway in Indonesia. Although the construction of this toll road is financed by the state budget and foreign debt, the process involves a contractor from South Korea.

The Indonesian government also understands the critical role of infrastructure establishment for development. The 2015-2019 National Medium-Term Development Plan emphasizes that infrastructure development is one of the national priority agendas to create a competitive nation and to increase the productivity of society. A huge challenge faced in providing infrastructure is the high value of financing funds. The investment needed for the period of 2015-2019 is IDR 4,796 trillion - a revised figure from the previous estimate of IDR 5,519 trillion - and of that, approximately $40 \%$ derives from the Public Works and Housing sector (i.e., roads, water resources, clean water and waste, and housing). On the other hand, there is a limited capability of both central and regional governments. Government through the State/Regional Budget can only cover around $41.25 \%$ of the total cost; the remaining cost of $22.23 \%$ is expected to be financed by State-Owned Enterprises and $36.52 \%$ by business entities through the PPP scheme.

By considering the crucial role of PPP in infrastructure development and the lack of study that summarizes the PPP research in Indonesia, a review upon the literature on PPP issues in Indonesia is needed. This systematic literature review was carried out to summarize what has been written about PPP in Indonesia. A systematic literature review is an appropriate way to provide a brief but comprehensive overview of a developing topic by providing academic evidence (Petersen, 2019). Publications published in international and national journals are summarized in this study so that readers may discover the research trends that have been carried out regarding PPP issues in Indonesia. The systematic literature review is expected to answer these questions:

1. What is the trend of PPP research in Indonesia between the period of 2002 and 2019 ?

2. How is the result of the "research gap" categorization of PPP research topics in Indonesia using a structured literature review study method?

\section{METHODOLOGY}

This study uses a qualitative method with a thematic, structured literature review approach that utilizes secondary data obtained through literature data collection techniques on research articles discussing PPP in Indonesia. Sampled articles are collected from the Portal Sinta, Portal Garuda, and Google Scholar. The research articles are collected, selected, and grouped using 
interpretive paradigm methods, then a deeper understanding of the PPP research topic in Indonesia is conducted based on categories made thematically to generate a "research gap" that can be used as a guide and reference for future research.

The sampling technique used is nonprobability sampling with a systematic sampling technique. The research sample obtained is based on the following criteria:

1. Research articles were obtained from the Portal Sinta, Portal Garuda, and Google Scholar.

2. Searching the research articles is carried out with the following keywords: KPBU (Kerjasama Pemerintah Badan Usaha or PPP in Bahasa Language), KPS (Kerjasama Pemerintah Swasta in Bahasa Language), PPP, Infrastructure, Accounting, and Indonesia.

The total sample in this study was 107 articles written in the period between 2002 and 2019 . The total sample is obtained after strict article selection with criteria:

1. Taking samples from different citations so that it is possible that the same article is listed in various places. Therefore, articles that are duplicated in other citations must be excluded from the sample.

2. Paper in the form of research articles such as theses, articles, or unpublished papers and articles are not used as samples.

3. Sample articles must be articles whose main discussion is about PPP and sampling is obtained in Indonesia, so articles whose discussion is outside the theme must be excluded from the sample. In a case where one of the three categories is not fulfilled then the article is excluded from the study sample.

4. Accordingly, the data completeness is checked. If the whole article is not available or only an abstract is present, it is also excluded from the sample.

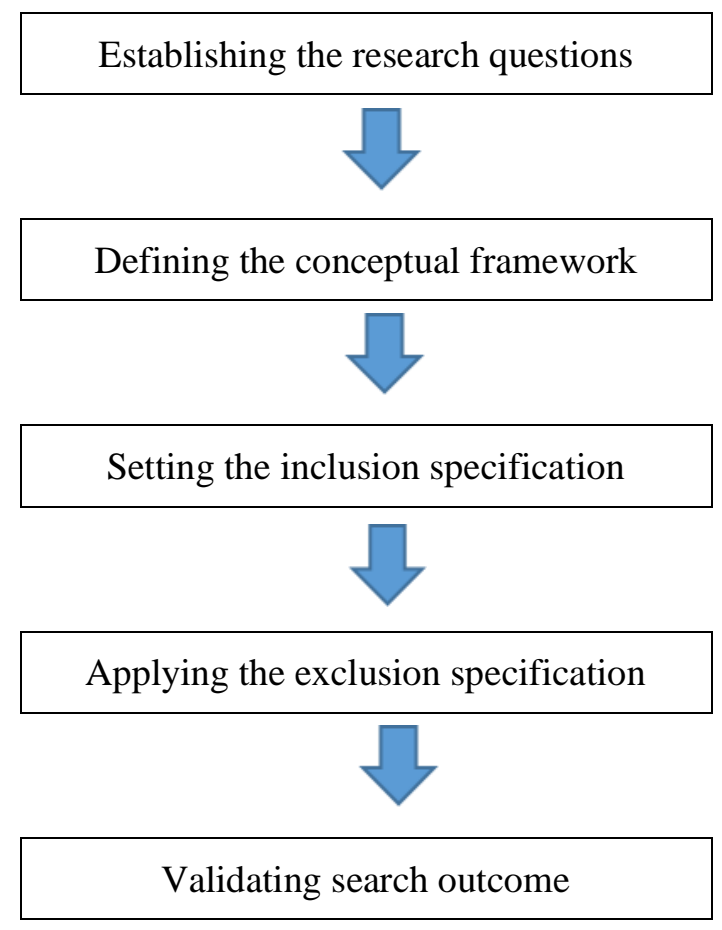

Figure 1 The research framework for this study 
The following table is detailed information regarding the time of sample data withdrawal:

Table 1 Time Sampling and Keywords

\begin{tabular}{|c|c|c|c|c|c|c|}
\hline No & Source & Keywords & Date & Time & Result & $\begin{array}{l}\text { Relevant } \\
\text { Papers }\end{array}$ \\
\hline \multirow[t]{6}{*}{1} & \multirow[t]{6}{*}{$\begin{array}{l}\text { Google } \\
\text { Scholar }\end{array}$} & $\begin{array}{l}\text { "PPP" and } \\
\text { "INFRASTRUCTURE } \\
\text { " and "INDONESIA" }\end{array}$ & 23 Agustus 2019 & $15: 44$ & 36.100 & 41 \\
\hline & & "ACCOUNTING" and & 25 Agustus 2019 & 16.50 & 25.200 & 3 \\
\hline & & "KERJASAMA & & & & \\
\hline & & PEMERINTAH DAN & 26 Agustus 2019 & $13: 27$ & 120 & 25 \\
\hline & & $\begin{array}{l}\text { BADAN USAHA" } \\
\text { "KERJASAMA }\end{array}$ & & & & \\
\hline & & $\begin{array}{l}\text { PEMERINTAH DAN } \\
\text { SWASTA" }\end{array}$ & 29 Agustus 2019 & $18: 39$ & 363 & 31 \\
\hline \multirow[t]{6}{*}{2} & \multirow[t]{6}{*}{ Sinta } & "KPBU" & 11 September 2019 & $17: 00$ & 8 & 2 \\
\hline & & $\begin{array}{l}\text { "PUBLIC PRIVATE } \\
\text { PARTNERSHIP" }\end{array}$ & 11 September 2019 & $17: 00$ & 10 & 3 \\
\hline & & "KERJASAMA & & & & \\
\hline & & PEMERINTAH DAN & 11 September 2019 & $17: 05$ & 5 & 0 \\
\hline & & $\begin{array}{l}\text { BADAN USAHA" } \\
\text { "KERJASAMA }\end{array}$ & & & & \\
\hline & & $\begin{array}{l}\text { PEMERINTAH DAN } \\
\text { SWASTA" }\end{array}$ & 11 September 2019 & $17: 05$ & 10 & 2 \\
\hline \multirow[t]{13}{*}{3} & \multirow[t]{13}{*}{ Garuda } & $\begin{array}{l}\text { "KPBU" } \\
\text { "KERJASAMA }\end{array}$ & 11 September 2019 & $17: 35$ & 1 & 0 \\
\hline & & PEMERINTAH DAN & 11 September 2019 & $17: 35$ & 0 & \\
\hline & & BADAN USAHA" & & & & \\
\hline & & "KERJASAMA & & & & \\
\hline & & PEMERINTAH DAN & 11 September 2019 & $17: 35$ & 0 & \\
\hline & & SWASTA" & & & & \\
\hline & & "KERJASAMA & & & & \\
\hline & & $\begin{array}{l}\text { PEMERINTAH DAN } \\
\text { BADAN USAHA DI }\end{array}$ & 11 September 2019 & $17: 35$ & 0 & \\
\hline & & $\begin{array}{l}\text { BADAN USAHA DI } \\
\text { INDONESIA" }\end{array}$ & & & & \\
\hline & & "KERJASAMA & & & & \\
\hline & & PEMERINTAH DAN & 11 September 2019 & $17: 35$ & 0 & \\
\hline & & $\begin{array}{l}\text { SWASTA DI } \\
\text { INDONESIA" }\end{array}$ & & & & \\
\hline & & TOTAL & & & 61.817 & 107 \\
\hline
\end{tabular}

\section{RESULTS AND DISCUSSION}

\subsection{The trend in the number of scientific publications}

Aligned with President Jokowi's government focus on infrastructure development, publications on PPP have also increased and developed since the year of 2014. As can be seen in Figure 1 below. The results for 2019 are not the maximum results because this study was conducted in mid-2019. 


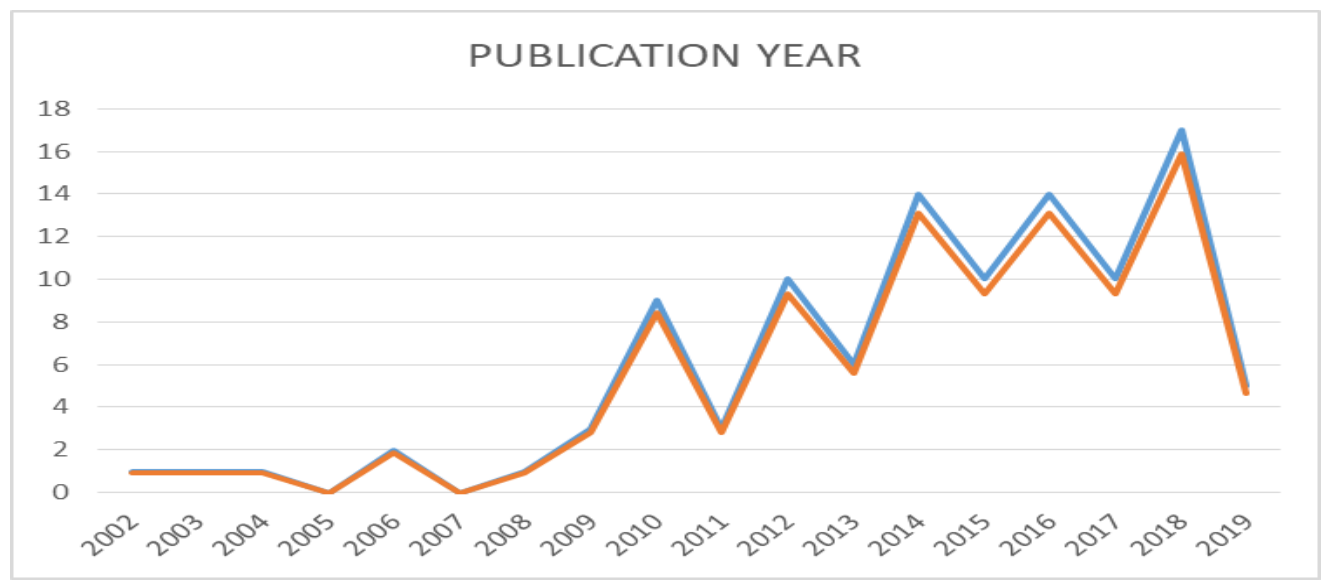

Figure 2 Article division based on the year the paper was written

\subsection{Research methods used}

The case study method is a popular research method in PPP research publications in Indonesia. This is not surprising because the case study research method is adequately popular in international PPP research (Petersen, 2019). On average, a case study discusses the PPP project, e.g., the airport case written by Berawi et al. (2014) that examines Soekarno Hatta International Airport Rail Link project or the Trans Sumatra (Palembang-Indralaya) toll road project written by Jefry, Sagita, and Permana (2018).

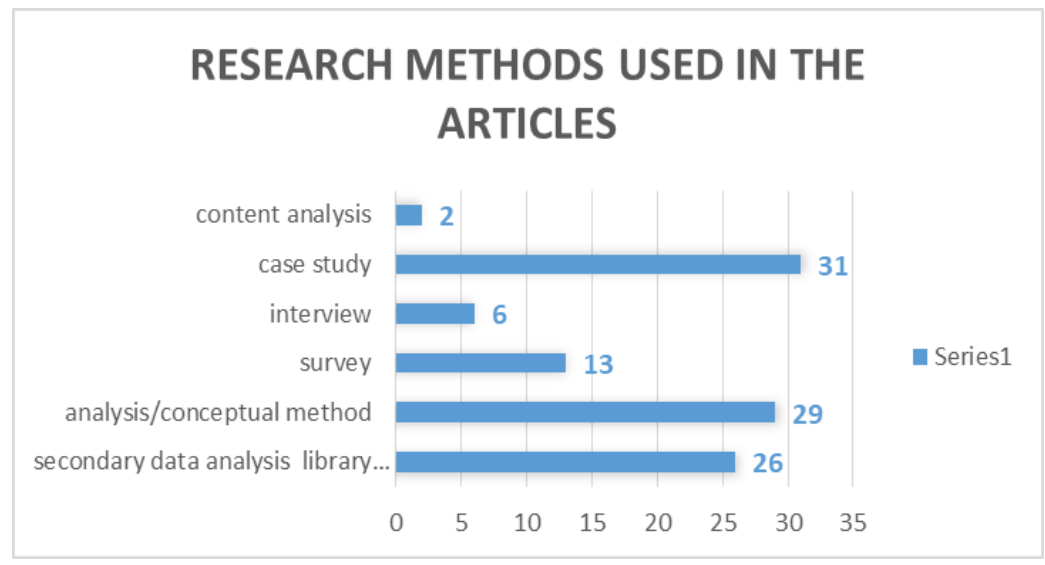

Figure 3 Article division based on the research method used

In general, case study research also conducts data collection through interviews and data, therefore one publication can fit into more than one category of research methodology.

\subsection{The Cluster of Science of the Publication}

Based on various publications on PPP analyzed, it can be seen that it is evidently dominated by research related to the technical sciences. As illustrated in Figure 4 below, other science clusters that also dominate the research topic are management, economics, and law sciences. No one has discussed the issue of PPP accounting or reporting, either from the side of the government or the parties from private entities. This contradicts the facts that PPP accounting issues are adequately popular in international publications, for example, Heald and Georgiou (2011) who examined PPP accounting issues in UK or Lopes and Caetano (2015)in Portugal. 


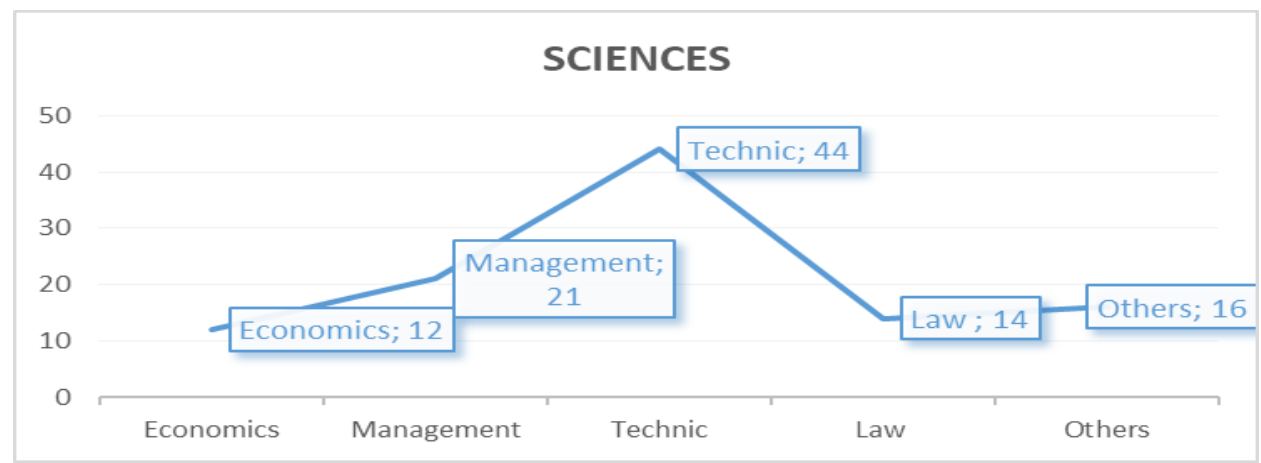

Figure 4 Article division based on the cluster of the science of the publication

\subsection{PPP Object Discussed in the Publication}

The majority of PPP objects in the publications we analyzed are road projects, followed by water supply and airport projects. This might reflect the well-known types of PPP projects in Indonesia. No one has discussed PPP projects for health facilities as there are many PPP publications in the UK (Froud \& Shaoul, 2001; Pollock et al., 2002; Shaoul, Stafford, \& Stapleton, 2008), or PPP on educational facilities (Khadaroo, 2008; Reeves \& Ryan, 2007).

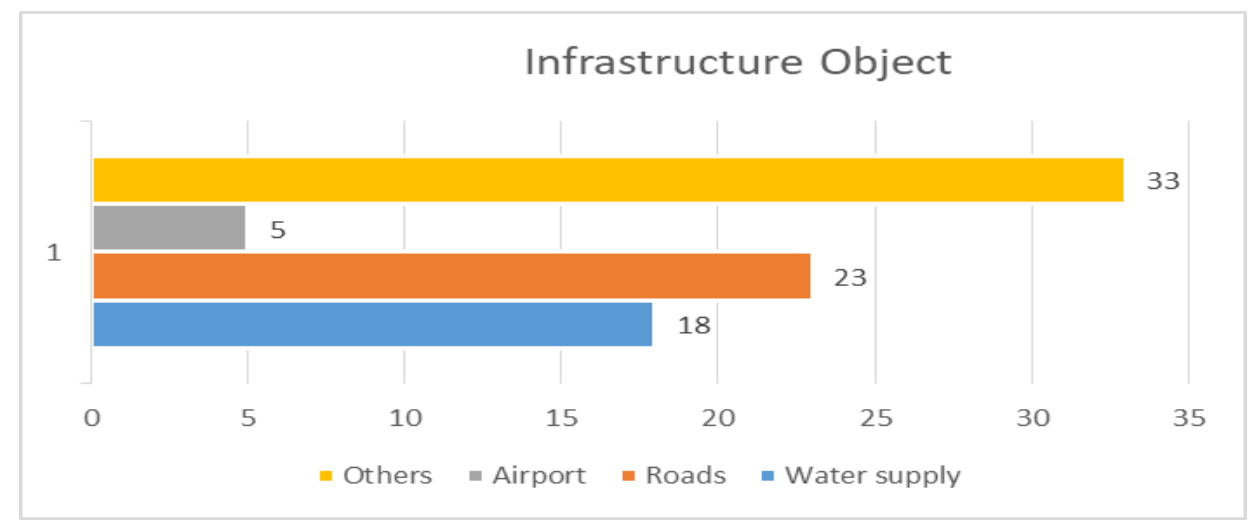

Figure 5 division based on PPP object discussed in the publication

\subsection{Research Topic}

Furthermore, we have also analyzed popular research topics in PPP publications in Indonesia. Many papers discussed case studies on how to implement a PPP project in Indonesia. In Figure 6 below, it can be seen that the issue of PPP implementation becomes a topic that attracts many researchers' attention. One paper can be mapped into more than one research topic. For instance, a paper that discusses the implementation of a PPP project can also discuss the Value for Money (VfM) issue. Many papers also discussed the risks from PPP projects, particularly risks from a technical perspective and also financial risks. No paper has discussed the accounting or accountability of the parties involved in the PPP. 


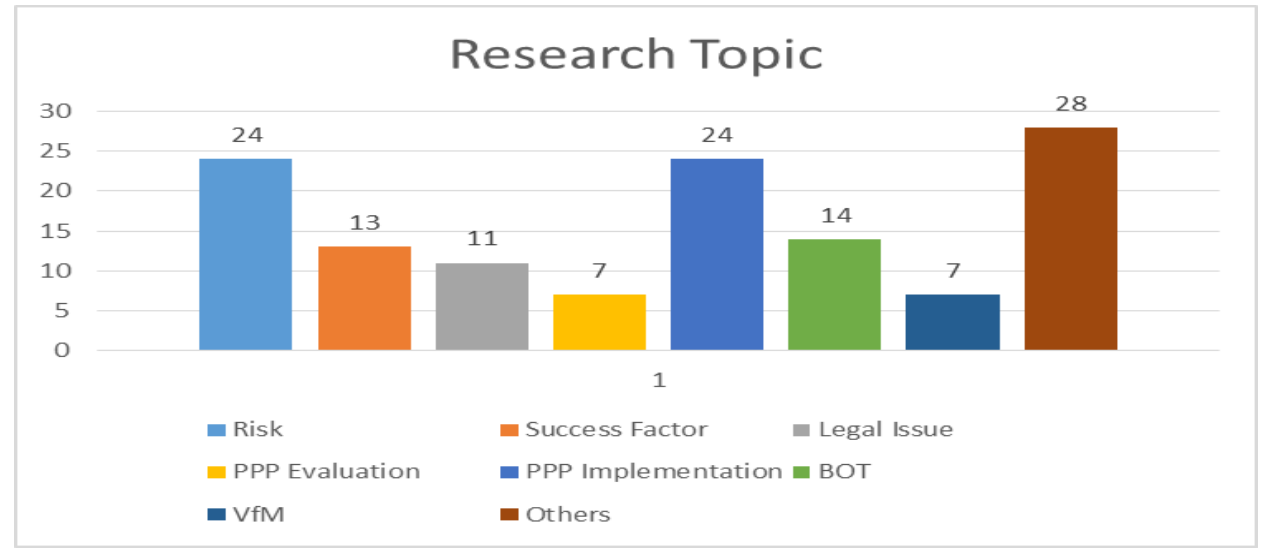

Figure 6 Article division based on the research topic

\section{CONCLUSION}

This study is a systematic literature review for international and national publications on the issue of PPP in Indonesia. The data for this study comes from papers that satisfy the searching criteria in several academic portals. The results obtained are a positive trend for the number of PPP publications over the last five years, most likely because due to the increasingly important infrastructure issues by the government. The commonly used research method is the case studies and many authors are from the engineering science cluster. The object of PPP research in Indonesia is still focused on roads and water supply that reflects infrastructure projects that are quite popular to be built with PPP funding mechanisms. The research topics that are widely discussed in research publications are case studies of PPP project implementation, discussion of risks in PPP projects and the Built Operate Transfer scheme in PPP projects. Research publications on accounting reporting, accountability, PPP taxation issues as well as the sociological issues of the PPP's impact on the surrounding community are highly rare. These topics can come to the attention of subsequent researchers in developing literature on PPP in Indonesia.

\section{REFERENCES}

Acerete, J. B., Shaoul, J., Stafford, A., \& Stapleton, P. (2010). The cost of using private finance for roads in Spain and the UK. Australian Journal of Public Administration, 69, S48-S60.

Akbiyikli, R., Dikmen, S. U., \& Eaton, D. (2011). Private finance initiative (PFI) for road projects in UK: Current practice with a case study. Promet-Traffic\&Transportation, 23(3), 215-223.

Berawi, M. A., Susantono, B., Dikun, S., Ilyas, T., Rahman, H. Z., Berawi, A. R. B., .. . Petroceany, J. S. (2014). Development of the Soekarno-Hatta International Airport Rail Link Project Using the Value Engineering Method: Creating Value for Money. Makara Journal of Technology, 18(3), 109-114.

Boardman, A. E., \& Vining, A. R. (2012). The political economy of public - private partnerships and analysis of their social value. Annals of public and cooperative economics, 83(2), 117-141.

Broadbent, J., \& Laughlin, R. (2003). Public private partnerships: an introduction. Accounting, Auditing \& Accountability Journal, 16(3), 332-341.

Froud, J., \& Shaoul, J. (2001). Appraising and evaluating PFI for NHS hospitals. Financial Accountability \& Management, 17(3), 247-270. 
Guthrie, J. (1998). Australian experiences of output based budgeting: a critical reflection. Paper presented at the Australasian Evaluation Society 1998 International Conference Proceedings.

Heald, D., \& Georgiou, G. (2011). The substance of accounting for public - private partnerships. Financial Accountability \& Management, 27(2), 217-247.

Hodge, G. A., \& Greve, C. (2009). PPPs: The passage of time permits a sober reflection. Economic Affairs, 29(1), 33-39.

Iossa, E., \& Saussier, S. (2018). Public private partnerships in Europe for building and managing public infrastructures: an economic perspective. Annals of public and cooperative economics, 89(1), 25-48.

Jefry, A., Sagita, L., \& Permana, A. (2018). The Implementation of Value for Money Quantitative Analysis on Infrastructure Projects in Indonesia. Journal of Infrastructure Policy and Management, 1(01), 43-55.

Khadaroo, I. (2008). The actual evaluation of school PFI bids for value for money in the UK public sector. Critical Perspectives on Accounting, 19(8), 1321-1345.

Lopes, A. I., \& Caetano, T. T. (2015). Firm-level conditions to engage in public-private partnerships: What can we learn? Journal of Economics and Business, 79, 82-99.

Petersen, O. H. (2019). Evaluating The Costs, Quality, And Value For Money Of Infrastructure Public - Private Partnerships: A Systematic Literature Review. Annals of public and cooperative economics, 90(2), 227-244.

Pollock, A. M., Shaoul, J., \& Vickers, N. (2002). Private finance and "value for money" in NHS hospitals: a policy in search of a rationale? Bmj, 324(7347), 1205-1209.

Reeves, E., \& Ryan, J. (2007). Piloting public-private partnerships: Expensive lessons from Ireland's schools' sector. Public money and management, 27(5), 331-338.

Shaoul, J., Stafford, A., \& Stapleton, P. (2008). The cost of using private finance to build, finance and operate hospitals. Public money and management, 28(2), 101-108. 